\title{
Effects of Institutional Framework Lapses in Solid Waste Management; Case of Ngomongo, Nairobi, Kenya
}

Bessy Kathambi ( $\sim$ k22bessy@gmail.com )

University of Nairobi https://orcid.org/0000-0002-8826-2798

Florence Akinyi Ogutu

University of Nairobi College of Agriculture and Veterinary Sciences

\section{Research}

Keywords: Institutional frameworks, Solid Waste Management, Ngomongo, Nairobi City, Kenya

Posted Date: May 7th, 2021

DOl: https://doi.org/10.21203/rs.3.rs-475257/v1

License: (c) (i) This work is licensed under a Creative Commons Attribution 4.0 International License.

Read Full License 


\section{Abstract}

Institutional frameworks serve as vehicles for proper solid waste management. Lapses in institutional structures create ecological disasters that affect public health and environmental degradation. Municipal solid waste management is a critical subject worldwide, and removal and control of municipal solid waste remain a global task, specifically in developing countries. The case of Ngomongo illustrates lapses in waste institutions in Nairobi City. The research design for the study used a mixed-method where primary data was collected using transect walk, questionnaires with 385 households administered, and satellite images. Focus group discussions and key informant interviews used to ensure the validity and reliability of the data. The results show the lapses that exist in institutional frameworks in Nairobi City as supported by the objective of the study. The effects demonstrated by the doubled number of minilandfills, open waste sites on the roadside over the decade.

\subsection{Introduction}

Institutions are critical when it comes to the management of solid waste because they guarantee stability and facilitate collaboration, ease transaction expenses, arbitrate disputes, and generate information. Institutional framework settings are crucial for the policy outcome. Also, interactions between actors take place. A lapse in them results in a devastating effect on the environment[1].

In Nairobi City County (NCC), SW institutions include; the Ministry of Environment and Natural Resources, National Environmental Management Authority (NEMA), Nairobi City County, Water resource management (WRM), and Kenya National Cleaner production center (KNCPC) [2]. KNCPC promotes waste reduction and prevention through sustainable consumption and production. These are regulatory institutions that foresee the formulation and implementation of policies/ regulations/ acts/ by-laws. Water Resource Management, responsible for water quality, pollution of water sources by waste, and other pollutants prohibited [3]. Others are those who do the collection of waste and disposal e.g. private service providers, National Governmental Organizations (NGOs, Community based Organizations (GBOs), and waste recyclers $[4,5]$.

Rapid urbanization is a growing challenge of solid waste management in Nairobi City County because of the increased waste generation with no marching remedial measures. The expanse of waste not met by the institutional framework structures in place and is evident with heaps of garbage on roadsides, estate gates, among others [6-8]. SW institutions in NCC take on different roles in solid waste management that have a duplicate mandate becoming a hindrance to the enforcement of SW policies, regulations, by-laws, acts. The challenges come in terms of personnel, infrastructure, technology, financial sustainability, given low priority of what SW is, advanced by the perception that waste is a none resource $[4,9]$.

Lack of Accountability, compromised integrity characterizes these institutions, which run with overlapping mandates. The conflict that exists in these institutions illustrated by Nairobi City County, department of environment and NEMA, where a double payment of the SW license by SW operators to collect waste, 
disposal of trash to the designated landfill in Dandora. Also, the problem of curtails who have established an anarchist system separate from the formal system, neither NCC nor NEMA can regulate them [3, 9$11]$.

The effects of solid waste institutional lapses illustrated by the case of Ngomongo in Nairobi City show the significance of improved institutional frameworks. Ngomongo is within NCC and uniquely located in a densely populated area with double waste generated. Historically, looking back, in 2003, it had the least waste generation; the population had not rapidly grown. Within the next 14 years, waste generation had increased, and the people had doubled with minimal institutional capacity to handle waste, thus the uprising mini landfill $[9,12-14]$.

\subsection{Conceptual Framework:}

\subsection{Materials And Methods}

The conceptual framework (Fig. 1) highlights the enhanced institutional framework on SWM in NCC includes; monitoring and evaluation of SWM policies, better coordination of stakeholders, improved SWM enforcement, a sustainable SWM in NCC.

The study used a mixed research design and to triangulate data collected, the three sub-counties, Kibra, Embakasi, and Lavington, demarcated purposely using a semi-structured questionnaire. Additionally, transect walk used to narrow down on Ngomongo for case illustration where satellite images used. The study used institutional and capacity building theories to expound on the institutional lapses in solid waste management. Institutional theory elucidates how institutions operate and how the different actors interact either together or incoherent for an effective institutional structure [15-17]. Capacity building theory comprises empowering institutions, individuals, and communities to execute functions and solve problems to attain the progress of their goals satisfactorily $[18,19]$. Ngomongo is in Nairobi City County, located between middle and low-income households in terms of social-economic status, depicting the face of the city. It is densely populated, with no proper reliable waste infrastructure, that is why Ngomongo was instrumental in discussing institutional lapses in SWM in Nairobi City [20].

\subsection{Results}

\section{Lapses in Institutional Frameworks for SWM for case study of Ngomongo, Nairobi County in 2003}

\section{Impacts of Institutional Frameworks on SWM in Nairobi City County}

Majority of the respondents agreed that the impacts of lapses in institutional frameworks for SWM have huge impact on the personal and environmental health. The impacts range from mushrooming illegal dumping sites to blocked drains and busted sewers due to improper waste disposal and collection in Nairobi County. 


\section{Enhanced SWM Institutional Frameworks Increase Coordination and Enforcement in Nairobi City County}

Majority of the respondents agreed that enhanced institutional frameworks lead to positive coordination of SWM stakeholders as well as enforcement of the SWM policies in Nairobi City council. Results indicate opportunity to enhance SWM coordination in Nairobi City County and the significance of improving institutional frameworks through capacity building, training and financial prudence.

\subsection{Discussions}

The case of Ngomongo supports the ideology that there are lapses in the institutional framework in Nairobi City County. Rapid population growth with minimal substantial waste infrastructure impacts in institutions responsible for SWM. Hence, there are inadequacies in terms of capacity, collection and disposal equipment, funding, skilled personnel, coordination of the SWM actors for collection and disposal, stakeholders' involvement, compliance to the policies and regulations for WM, which is visible in most developing countries $[10,21]$.

The majority of the respondents agreed that the impacts of SW institutional lapses arrays from uncontrolled dumping sites due to improper disposal and collection of waste, contaminated water surfaces, increased dumping of waste along with water sources, for instance, Nairobi River and Ngong River. The improper removal of waste within the Nairobi city has devastating effects on the environment and public health [5, 22-25].

Waste generation in developing countries is predominately organic, with only a small percentage recycled, as witnessed in Nairobi city, Kenya. NCC has unlimited illegible dumpsites, evident in the case of Ngomongo[26-28]. Importantly, waste recycled to reduce the pollution on the environment, provide job opportunities, as evident in developed countries, to address the challenges of SWM $[16,29]$. There is an institutional framework lapse in the recycling of waste, no mechanism for separating waste, no capacity at source, and the household level, no waste separation. Overlapping coordination result in failed frameworks for SW in Nairobi City, which is mostly done by informal waste pickers who have minimal technological capacity. Formal recyclers are insufficient, and source recovery is at $10 \%$, operating costs unrecovered [9]. The majority of the respondents agreed that enhanced institutional frameworks would significantly improve institutional structures through capacity building, training, and financial sustainability $[3,9]$.

Evidential effects of institutional frameworks for SWM, the case of Ngomongo, illustrate the lapse, conflicting regulations with overlapping mandates. The actors, the public, civil society, NCC, NEMA, and ministries of environment and Natural resources and Water Resource Authority [30, 31]. Indiscriminate disposal by the public shows the absence of public education on SWM focusing on critical areas, for instance, proper waste disposal, waste reduction, and environmental stewardship [29, 32]. Also, insufficient institutional, financial capacities, and management systems affect performance, restraining the interpretation of policy and legislation on SWM in practice [24, 33-35]. 
The majority of the respondents noted that enhanced institutional frameworks as the most critical component of sustainable solid waste management in NCC through capacity building, training, and financial sustainability [7, 36]. The case of Ngomongo illustrates the absence of SWM with monitoring and evaluation, coordination, and enhanced SWM infrastructure, which is an impediment to SWM policy enforcement $[9,33,37]$. Ngomongo underscores the lapses in solid waste institutional frameworks in Nairobi City County

\subsection{Conclusion}

The findings demonstrate that effective institutional frameworks in any context are of critical importance and constitute the single most crucial component of sustainable SWM. The research further shows the significance of capacity building, technological upgrade, financial prudence, and stakeholder engagement in SW institutional frameworks are fundamental. Ngomongo in Nairobi City explicates the lapses and effects on SWM, which impacts on the environment and enhances unsustainable waste management.

\section{Declarations}

\section{Availability of data and materials}

All data generated or analyzed during this study are available

\section{Competing interests}

The authors declare no potential conflicts of interest concerning the research, authorship or publication of this article.

\section{Funding}

The research described in this paper received no specific grant from any funding agency.

\section{Authors' contributions}

\begin{tabular}{|ll|}
\hline Author & Contribution \\
\hline $\begin{array}{l}\text { Dr. Bessy Kathambi and Dr. Florence } \\
\text { Ogutu }\end{array}$ & $\begin{array}{l}\text { Research design, data collection and manuscript } \\
\text { preparation. }\end{array}$ \\
\hline $\begin{array}{l}\text { Dr. Bessy Kathambi and Dr. Florence } \\
\text { Ogutu }\end{array}$ & Manuscript preparation \\
\hline
\end{tabular}

All authors read and approved the final manuscript.

\section{Acknowledgements}


The authors would like to acknowledge the administrative authority of Nairobi City County, department of environment, solid waste, and water resource; for providing research data documentation, without which this study would not have been possible.

\section{References}

1. World Bank (2008) Cities of Hope? Governance, Economic, and Human Challenges of Kenya's Five Largest Citie. World Bank, Washington DC.

2. Nairobi City Council (2015) Nairobi City County Solid Waste Act 2015.

3. Nairobi City Council (2015) Nairobi City County Solid Waste Act 2015.

4. Ministry of environment and Forestry (2019) Revised Draft, National susutainable waste management policy.

5. NEMA (2014) The national solid waste management strategy.

6. Al-Khatib IA, Kontogianni S, Nabaa, AH, Alshami N, Al-Sari MI (2015) Public perception of hazardousness caused by current trends of municipal solid waste management. J Waste Manage 323-330.

7. Butu AW, Ageda BR, Bichi AA (2013) ENVIRONMENTAL IMPACTS OF ROADSIDE DISPOSAL OF MUNICIPAL SOLID WASTES IN KARU, NASARAWA STATE, NIGERIA. International Journal of Environment and Pollution Research 1:1-19.

8. Mutisya E, Yarime M (2011) Understanding the Grassroots Dynamics of Slums in Nairobi: The Dilemma of Kibera Informal Settlements. 2:197-213.

9. NEMA (2016) Waste Management Regulations 2016. NEMA, Nairobi.

10. Bundhoo ZMA (2018) Solid waste management in least developed countries: current status and challenges faced. J Mater Cycles Waste Manag 20:1867-1877.

11. Oyake LO (2017) Awareness of environmentally sound waste management by communities and municipalities in Kenya. UNDP, Kenya.

12. Allison K, Von Blottnitz H (2010) Solid waste management in Nairobi, a situational analysis, technical document accompanying the integrated solid waste management plan. UNEP, Nairobi.

13. Okot-Okumu J (2012) Solid Waste Management in African Cities - East Africa. Waste Management An Integrated Vision. https://doi.org/10.5772/50241.

14. Solomon AO (2011) The role of households in solid waste management in East Africa capital cities. https://doi.org/10.3920/978-90-8686-747-9.

15. Delbridge R, Edwards T (2013) Inhabiting Institutions: Critical Realist Refinements to Understanding Institutional Complexity and Change. Organization Studies 34:927-947.

16. Wilson DC, Velis CA, Rodic L (2013) Integrated sustainable waste management in developing countries. Proceedings of the Institution of Civil Engineers - Waste and Resource Management 166:52-68. 
17. Wilson DC, Velis CA (2015) Waste management - still a global challenge in the 21st century: An evidence-based call for action. Waste Manag Res 33:1049-1051.

18. UNEP (2002) Capacity building for sustainable development: an overview of UNEP environmental capacity development initiatives. UNEP.

19. UNEP, ISAWA (2015) Global Waste Management Outlook. Osaka: United Nations Environment Programme. UNEP/ ISAWA, Osaka.

20. Nairobi Metro 2030 (2008) Ministry of Nairobi Metropolitan Development. Nairobi Metro, Nairobi.

21. Ogutu, FA (2019) Assessment of the effectiveness of the policy framework in solid waste management in Nairobi city county. University of Nairobi.

22. Guerrero LA, Maas G, Hogland W (2013) Solid waste management challenges for cities in developing countries. Waste Management 33:220-232.

23. Rodić L, Wilson D (2017) Resolving Governance Issues to Achieve Priority Sustainable Development Goals Related to Solid Waste Management in Developing Countries. Sustainability 9:404.

24. UNEP (2015) Global Waste Management Outlook. UNEP.

25. Waweru S, Kanda EK (2012) Municipal Solid Waste Management in Kenya: A Comparison of Middle Income and Slum Areas.

26. Buniamin S, Ahmad N, Rauf FHA, Johari NH, Rashid AA (2016) Green Government Procurement Practices (GGP) in Malaysian Public Enterprises. Procedia Economics and Finance 35:27-34.

27. Ogutu, FA, Kimata D, Kweyu R (2019) The Role of Environmental Governance in Solid Waste Management, Policy Implementation in Nairobi County. CER. https://doi.org/10.7176/CER/11-10-06.

28. UN-HABITAT (2009) Urban indicators guidelines: better informa-tion, better cities, Nairobi. UNHABITAT.

29. Harir Al, Kasim R, Ishiyaku B (2015) Resource Potentials of Composting the Organic Wastes Stream from Municipal Solid Wastes Compositions Arising in Nigerian Cities. GEP 03:10-15.

30. Haregu TN, Ziraba AK, Aboderin I, Amugsi D, Muindi K, Mberu B (2017) An assessment of the evolution of Kenya's solid waste management policies and their implementation in Nairobi and Mombasa: analysis of policies and practices. Environment and Urbanization 29:515-532.

31. Ogutu, FA, Kimata D, Kweyu R (2019) A Spatial Analysis of Unplanned and Mushrooming Dumpsites and Environmental Governance in Nairobi County. JEES. https://doi.org/10.7176/JEES/9-10-17.

32. Haregu TN, Ziraba AK, Aboderin I, Amugsi D, Muindi K, Mberu B (2017) An assessment of the evolution of Kenya's solid waste management policies and their implementation in Nairobi and Mombasa: analysis of policies and practices. Environment and Urbanization 29:515-532.

33. Ogutu, FA, Kimata D, Kweyu R (2018) Factors affecting the use of environmental values and ethics in solid waste management in Nairobi city county. International Journal of Environmental and Health Sciences 1.

34. Scheinberg AM, Simpson Y, Gupt (2010) The Economics of the Informal Sector in Solid Waste Management. GTZ and CWG, Germany. 
35. Wilson DC (2007) Development drivers for waste management. Waste Manag Res 25:198-207.

36. Khatib I (2011) Municipal Solid Waste Management in Developing Countries: Future Challenges and Possible Opportunities. Integrated Waste Management - Volume II. https://doi.org/10.5772/16438.

37. TISA (2016) Budget Implementation inSolid Waste ManagementIn Nairobi City County. The Institute for Social Accountability, Nairobi.

\section{Figures}

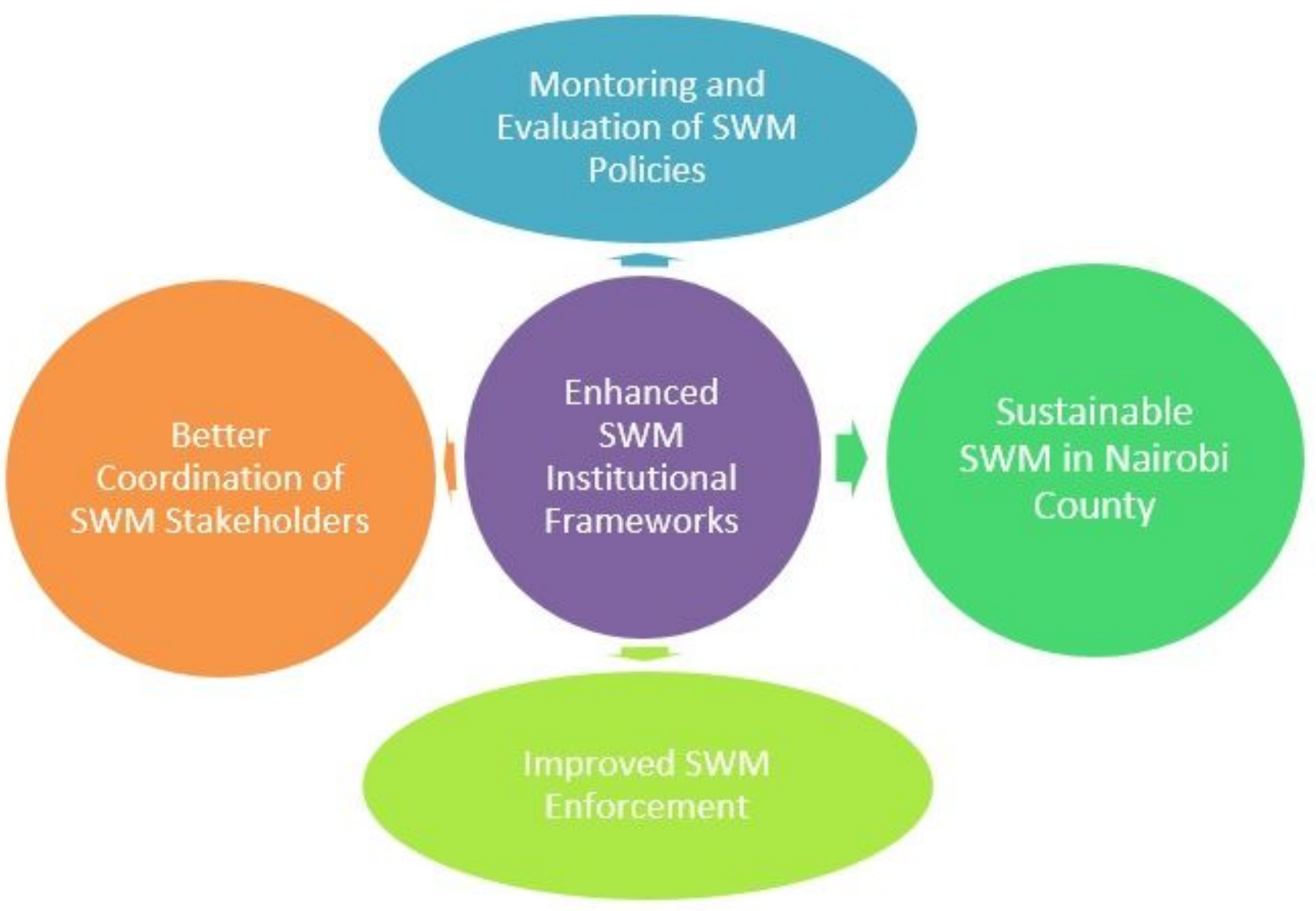

\section{Figure 1}

Enhanced Institutional Framework on SWM in Nairobi City County 


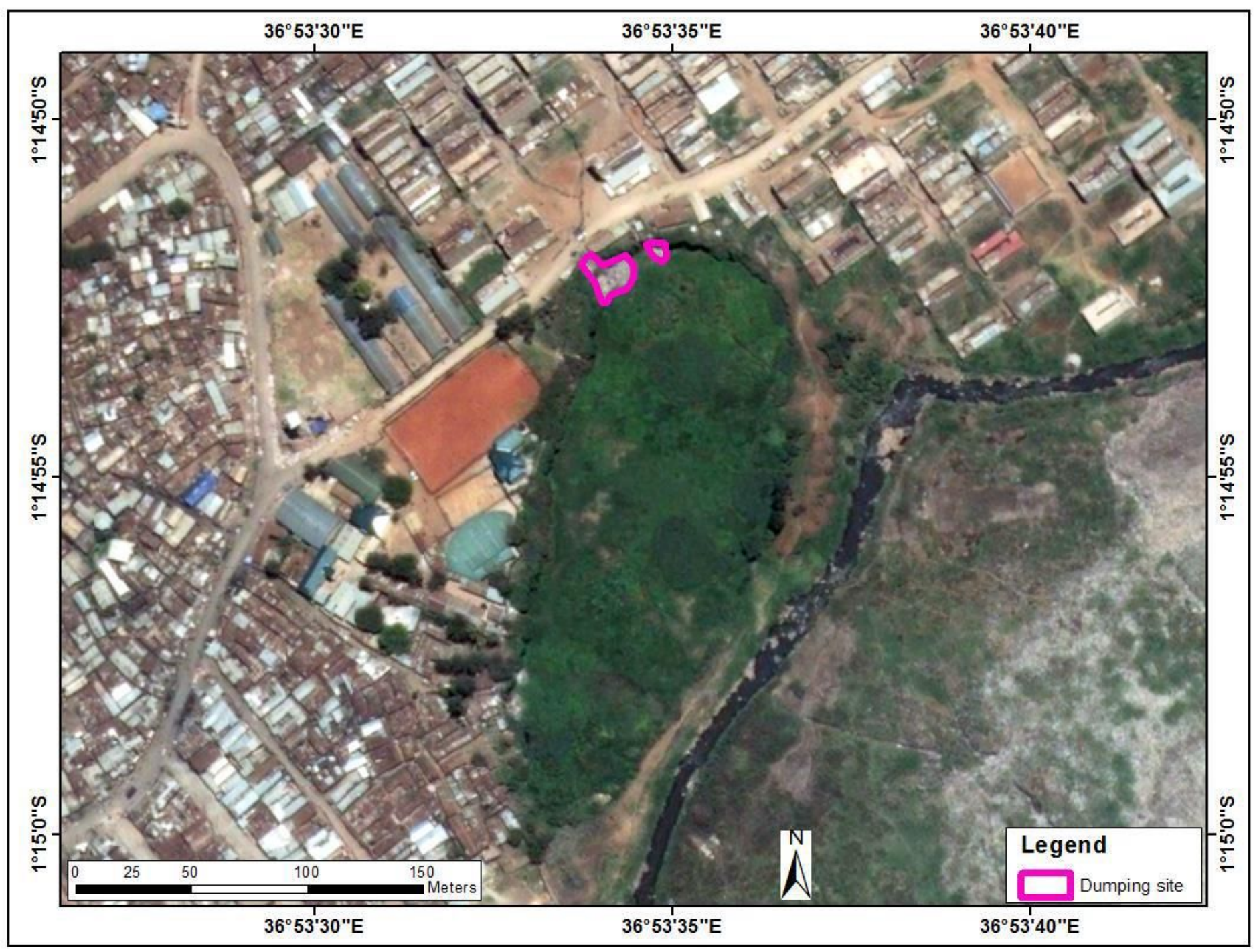

Figure 2

Lapses in Institutional Frameworks for SWM for the case study of Ngomongo, Nairobi County Ngomongo in 2003 (data source: Digital Globe) Note: The designations employed and the presentation of the material on this map do not imply the expression of any opinion whatsoever on the part of Research Square concerning the legal status of any country, territory, city or area or of its authorities, or concerning the delimitation of its frontiers or boundaries. This map has been provided by the authors. 


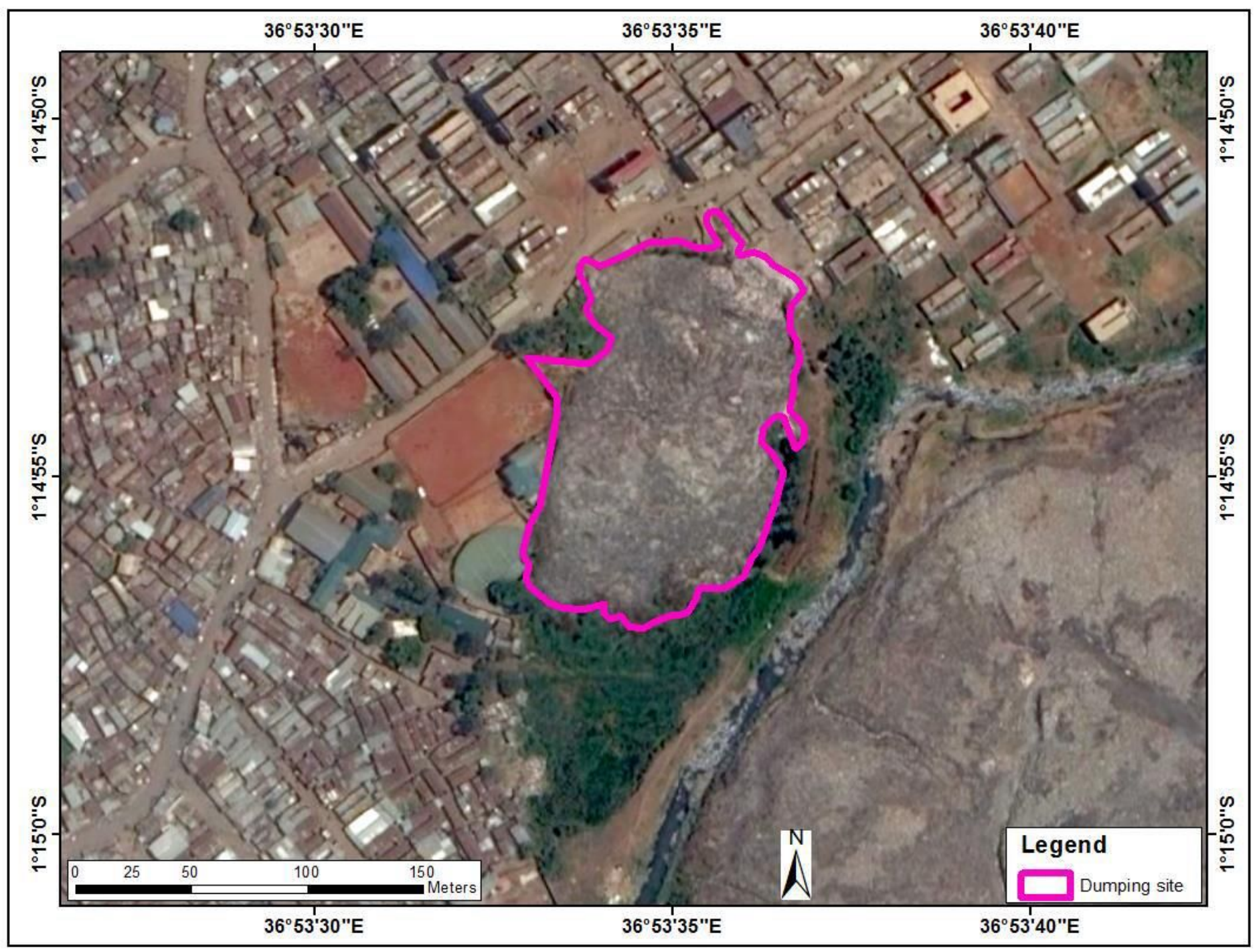

\section{Figure 3}

Evidential Effects of Institutional Frameworks for SWM for case study of Ngomongo, Nairobi County in 2017 Ngomongo in 2017 (data source: Digital Globe) Note: The designations employed and the presentation of the material on this map do not imply the expression of any opinion whatsoever on the part of Research Square concerning the legal status of any country, territory, city or area or of its authorities, or concerning the delimitation of its frontiers or boundaries. This map has been provided by the authors. 


\section{Impacts of SWM Institutional Framework Lapses}

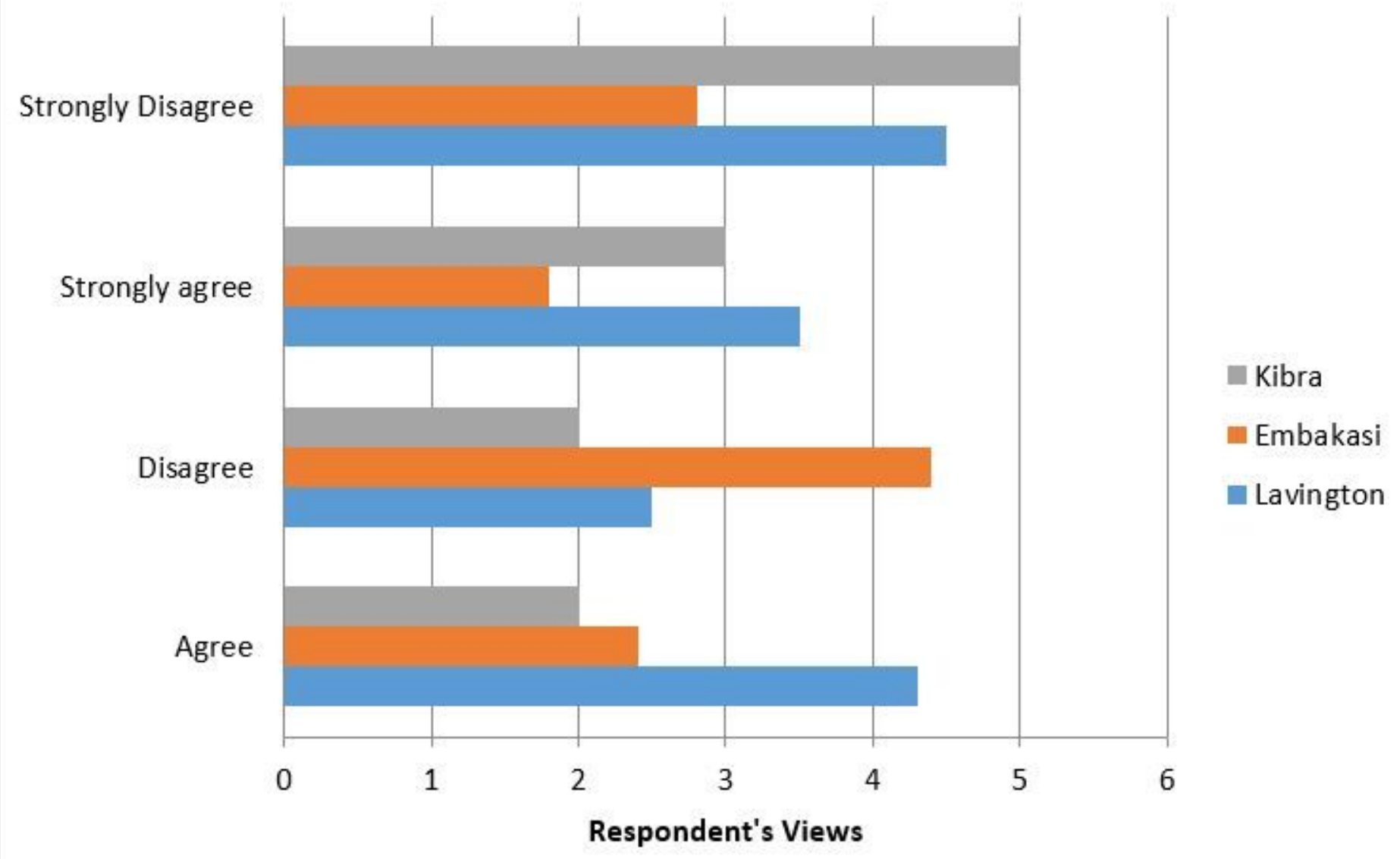

Figure 4

Impacts of Institutional Frameworks on SWM in Nairobi City County 


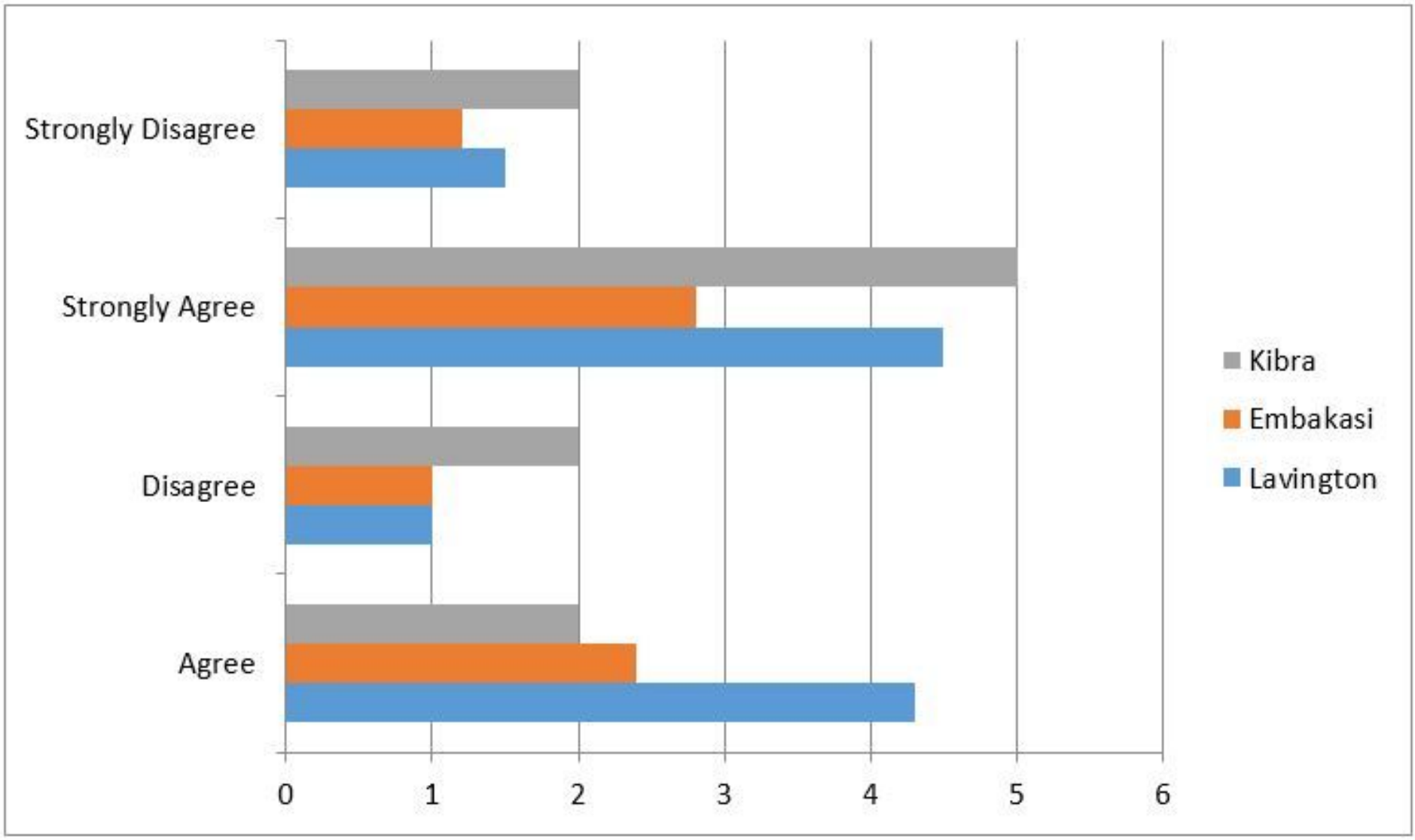

Figure 5

Enhanced SWM Institutional Frameworks Increase Coordination and Enforcement in Nairobi City County 